\title{
PENGARUH INSENTIF DAN PENGAWASAN TERHADAP PRODUKTIVITAS KERJA KARYAWAN PADA CV. VASSEL PALEMBANG
}

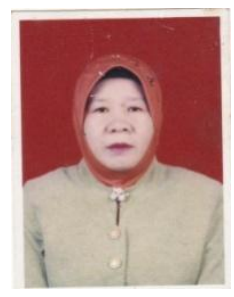

\author{
Oleh : \\ Akila \\ Dosen Fakultas Ekonomi Universitas PGRI Palembang \\ Email : Akilahj122@yahoo.com
}

\begin{abstract}
ABSTRAK
Penelitian ini bertujuan untuk mengetahui pengaruh insentif dan pengawasan terhadap produktivitas kerja karyawan pada CV. Vassel Palembang. Populasi dari penelitian ini adalah seluruh karyawan CV. Vassel sebanyak 34 orang. Pengambilan sampel dari penelitian ini teknik sampling jenuh. Tehknik pengumpulan data dalam penulisan ini yaitu kuesioner atau Angket. Teknik analisis data yang digunakan adalah analisis regresi linier berganda, analisis korelasi berganda, analisis koefisien determinasi, dengan pengujian hipotesis uji $\mathrm{t}$ dan uji $\mathrm{F}$ dengan bantuan software SPSS 22 for windows.

Hasil penelitian ini menunjukkan bahwa 1) Secara simultan terdapat pengajaruh insentif dan pengawasan terhadap produktivitas kerja karyawan pada CV. Vassel Palembang, 2) Secara parsial terdapat pengaruh insentif terhadap produktivitas kerja karyawan pada CV. Vassel Palembang, 3) Secara parsial juga ada pengaruh pengawasan terhadap produktivitas kerja karyawan pada CV. Vassel Palembang.
\end{abstract}

Kata Kunci : Insentif, pengawasan dan Produktivitas Kerja

PENDAHULUAN

\section{Latar Belakang Masalah}

Produktivitas kerja sering kita artikan sebagai kemampuan seseorang atau kelompok orang untuk menghasilkan barang atau jasa. Tujuan utama dari peningkatan produktivitas kerja karyawan adalah agar karyawan baik di tingkat bawah maupun di tingkat atas mampu menjadi karyawan yang efisien, efektif dan produktif. Seorang karyawan yang produktif adalah karyawan yang cekatan dan mampu menghasilkan barang atau jasa sesuai mutu yang ditetapkan dan waktu yang lebih singkat, sehingga akhirnya dapat tercapai tingkat produktivitas kerja karyawan yang tinggi. Dengan demikian penting bagi seorang pimpinan berusaha untuk meningkatkan produktivitas kerja karyawan, agar perusahaan dapat berkembang dan dapat mempertahankan usahanya.
Untuk mencapai tujuan suatu perusahaan maka peranan karyawan merupakan faktor penting. Selain itu waktu, tenaga, dan kemampuan benarbenar harus dimanfaatkan secara efisien dan seefektif bagi kepentingan perusahaan tersebut. Efisien dan efektivitas kerja karyawan sebagai sumber daya manusia dalam suatu perusahaan sangat penting bagi peningkatan produktivitas kerja di lingkungan perusahaan tersebut. Karena produktivitas kerja yang dihasilkan oleh karyawan mencerminkan keadaan karyawan yang bertanggung jawab terhadap tugas-tugas yang diberikan. Produktivitas kerja karyawan yang baik adalah produktivitas kerja yang optimal, yaitu yang sesuai dengan standar perusahaan yang mendukung tercapainya tujuan. Peningkatan produktivitas kerja karyawan akan membawa kemajuan. Oleh sebab itu upaya untuk meningkatkan produktivitas kerja karyawan penting 
untuk diperhatikan oleh perusahaan karena untuk mencapai tujuan dan kelangsungan perusahaan tergantung pada produktivitas kerja karyawan yang ada di dalamnya.

Faktor-faktor yang mempengaruhi produktivitas kerja karyawan (pekerja) diantaranya adalah insentif dan pengawasan. Insentif dan pengawasan merupakan hal yang sangat penting dalam setiap pekerjaan baik dalam instansi pemerintah maupun swasta. Upaya yang dapat dilakukan oleh suatu perusahaan untuk meningkatkan produktivitas kerja karyawan yaitu dengan cara pemberian insentif yang adil dan pengawasan yang baik dan berkelanjutan.

CV. Vassel adalah perusahaan yang bergerak dibidang Rubber Supplier dalam pemberikan insentif dan pengawasan terhadap karyawan belum dilakukan secara maksimal hal ini bisa dilihat dari rendahnya produktivitas kerja karyawan yang menyebabkan tujuan perusahaan tidak tercapai dengan baik karena terdapat tindakan yang tidak mendukung efektivitas dan efisiensi dalam melakukan pekerjaan. Akibatnya perusahaan harus menerima kerugian materil maupun immaterial karena pekerjaan karyawan yang selalu tidak tepat waktu.

Pemberian insentif pada CV. Vassel dalam bentuk gaji sering juga terjadi tidak sesuai dengan ketentuan yang telah ditetapkan oleh pemerintah. Upah/honor sering menjadi pemicu keengganan karyawan untuk menyelesaikan pekerjaannya dengan baik. Hal ini dikarenakan upah/honor yang merupakan hak karyawan diberikan dibawah standar yang berlaku secara umum. Upah/honor bahkan diberikan tidak secara proposional yang sesuai dengan tanggung jawab pekerjaan.

Disisi lain pelaksanaan pengawasan sangatlah penting dalam sebuah perusahaan, terutama terhadap karyawan. Pada dasarnya, setiap instruksi yang disampaikan kepada bawahan harus diawasi oleh pimpinan sehingga pimpinan pun mampu mengambil tindakan apabila ada terjadi kesalahan, kelalaian akan tugas yang dijalani oleh para karyawannya sehingga produktivitas karyawan semakin meningkat. Pengawasan sudah dilakukan oleh CV. Vassel namun dalam pelaksanaan masing sering terjadi kesalahan dan penyimpangan yang dilakukan oleh karyawan sehingg target yang telah ditetapkan tidak tercapai dengan maksimal.

Berdasarkan dari uraian diatas maka penulis tertarik untuk meneliti lebih lanjut dengan judul "Pengaruh Insentif dan Pengawasan Terhadap Produktivitas Kerja Karyawan pada CV. Vassel Palembang".

\section{Rumusan Masalah}

Berdasarkan latar belakang di atas, permasalahan yang dapat dirumuskan dalam penelitian ini sebagai berikut :

a. Apakah ada pengaruh insentif dan pengawasan terhadap produktivitas kerja karyawan pada CV. Vassel Palembang?

b. Apakah ada pengaruh insentif terhadap produktivitas kerja karyawan pada CV. Vassel Palembang?

c. Apakah ada pengaruh pengawasan terhadap produktivitas kerja karyawan pada CV. Vassel Palembang?

\section{Tujuan Penelitian}

Dari rumusan masalah di atas dapat diuraikan tujuan penelitian ini, yaitu untuk mengetahui:

a. Pengaruh insentif dan pengawasan terhadap produktivitas kerja karyawan pada CV. Vassel Palembang

b. Pengaruh insentif terhadap produktivitas kerja karyawan pada CV. Vassel Palembang

c. Pengaruh pengawasan terhadap produktivitas kerja karyawan pada CV. Vassel Palembang 


\section{TINJAUAN PUSTAKA}

\section{Insentif}

Insentif sebagai sarana motivasi atau daya perangsang yang mendorong karyawan untuk bekerja secara maksimal, yang dimaksudkan untuk mendapatkan penghasilan lebih di luar gaji atau upah yang telah di tentukan. Pemberian insentif dimaksudkan untuk memberikan tunjangan bagi para karyawan agar dapat memenuhi kebutuhan para karyawan dan keluarga mereka.

Menurut Suwatno dan Priansa (2011:234) insentif merupakan suatu yang merangsang minat untuk bekerja. Pemahaman ini merupakan pendapat yang baik apabila diterapkan pada suatu perusahaan, karena kinerja dan produktivitas perusahaan akan meningkat, hal tersebut akibat dari karyawan yang bekerja dengan optimal.

Menurut Hasibuan (2013:183), Insentif adalah daya perangsang yang diberikan kepada karyawan tetentu berdasarkan prestasi kerjanya agar karyawan terdorong meningkatkan produktivitas kerjanya dengan memberikan insentif yang mampu memberikan dorongan atau motivasi untuk bekerja, maka akan berpengaruh terhadap semangat kerja karyawan.

Menurut Yani (2012:146) insentif penghargaan dalam bentuk uang yang diberikan oleh suatu oganisasi atau perusahaan kepada karyawannya atas dasar prestasi kerja yang tinggi atau pada karyawannya yang bekerja melampaui standar yang telah ditentukan.

Dari beberapa definisi insentif menurut para ahli di atas maka penulis dapat menyimpulkan bahwa insentif adalah suatu alat sebagai motivasi atau pendorong karyawan untuk melakukan pekerjaan yang lebih baik guna mencapai produktivitas kerja yang diharapkan perusahaan.

\section{Pengawasan}

Pengawasan secara umum dapat didefinisikan sebagai cara suatu organisasi mewujudkan kinerja yang efektif dan efisien, serta lebih jauh mendukung terwujudnya visi dan misi organisasi.

Menurut Manullang (2012:173) pengawasan dapat diartikan sebagai suatu proses untuk menerapkan pekerjaan apa yang sudah dilaksanakan, menilainya, dan bila perlu mengoreksi dengan maksud supaya pelaksanaan pekerjaan sesuai dengan rencana semula. Menurut Handoko dalam Fahmi (2011:84) pengawasan dapat didefinisikan sebagai proses untuk "menjamin" bahwa tujuan-tujuan organisasi dan manajemen tercapai.

Hadibroto dalam Fahmi (2011:84) mengatakan bahwa pengawasan adalah kegiatan penilaian terhadap organisasi/kegiatan dengan tujuan agar organisasi/kegiatan tersebut melaksanakan fungsinya dengan baik dan dapat memenuhi tujuannya yang telah ditetapkan.

Brantas dalam Fahmi (2011:84) Pengawasan ialah proses pemantauan, penilaian, dan pelaporan rencana atas pencapaian tujuan yang telah ditetapkan untuk tindakan korektif guna penyempurnaan lebih lanjut.

Dari definisi di atas dapat disimpulkan bahwa pengawasan adalah suatu proses kegiatan pemantauan, pelaporan serta penilaian terhadap organisasi atau kegiatan atas pencapaian tujuan yang telah ditetapkan dan bila perlu mengoreksi dengan maksud supaya pelaksanaan pekerjaan sesuai dengan rencana semula.

\section{Produktivitas Kerja}

Secara umum yang dimaksud dengan produktivitas kerja adalah perbandingan antara hasil yang dicapai (output) dengan keseluruhan sumber daya yang digunakan (input). Konsep produktivitas dikembangkan untuk mengukur besarnya 
kemampuan menghasilkan nilai tambah atas komponen masukan yang digunakan. Secara sederhana produktivitas adalah perbandingan ilmu hitung antara jumlah yang dihasilkan dan jumlah setiap sumber yang digunakan selama kegiatan berlangsung. Produktivitas dapat diukur dari hasil produksi dan prestasi kerja karyawan terhadap perusahaan. Semakin tinggi hasil produksi atau prestasi kerja karyawan maka hal yang wajar untuk menaikan tingkat upah karyawan (Bangun, 2012:262).

Produktivitas merupakan suatu hasil dari tugas yang dikerjakan karyawan. Dalam suatu perusahaan, produktivitas penting dimiliki dalam rangka peningkatan hasil perusahaan. Produktivitas dipengaruhi oleh faktor kepuasan kerja kerja, sebagaimana dikatakan bahwa perusahaan yang mempunyai karyawan yang lebih puas cenderung lebih efektif bila dibandingkan dengan organisasi yang karyawannya kurang puas (Diana dkk, 2008:113).

Produktivitas kerja baik atau tidak tergantung pada tujuh faktor, yaitu: (a) sikap terhadap pimpinan; (b) ketepatan waktu kerja; (c) motivasi kerja; (d) lingkungan kerja; (e) bakat khusus; (f) kinerja menajerial; (g) sistem upah atau pengajian (Irianto, 2011:70).

Produktivitas adalah hubungan antara keluaran (hasil organisasi) dengan menekan yang diperlukan, yang dapat diperbaiki dengan cara memperbaiki rasio produktivitas dengan menghasilkan lebih banyak keluaran output yang lebih baik dengan tingkat masukan sumber daya tertentu (Wibowo, 2012:5).

Produktivitas adalah hasil kongkrit (produk) yang dihasilkan oleh individu atau kelompok selama satuan waktu tertentu dalam suatu proses kerja. Semakin banyak produk yang dihasilkan dalam waktu yang singkat dapat dikatakan bahwa tingkat produktivitasnya mempunyai nilai yang tingggi (Yuniarsih dan Suwatno, 2013:156).

Berdasarkan pendapat di atas dapat disimpulkan bahwa, produktivitas merupakan suatu hasil yang diperoleh dari tugas yang dikerjakan karyawan. Dalam suatu perusahaan, produktivitas penting dimiliki dalam rangka peningkatan hasil perusahaan.

\section{Penelitian Terdahulu}

a. Kartika Legawati (2014) Pengaruh Pengawasan Terhadap Produktivitas Kerja Karyawan Pabrik ( Kasus Karyawan Bagian Produksi PT. Pelita Agung Agrindustri di Duri). Hasil penelitian menunjukkan bahwa pengawasan berpengaruh sangat signifikan terhadap produktivitas kerja karyawan pabrik pada PT. Pelita Agung Agrindustri Duri.

b. Socha Summarjaya (2013) Pengaruh Pengawasan Terhadap Produktivitas Kerja Pegawai Kantor Camat Menyuke Kabupaten Landak. Hasil penelitian menunjukkan bahwa pengawasan berpengaruh positif terhadap produktivitas kerja pegawai Kantor Camat Menyuke Kabupaten Landak.

c. Siti Khafidhoh (2015). Pengaruh Insentif dan Jaminan Sosial Terhadap Produktivitas Kerja Karyawan Kantor Pada PT. Rea Kaltim Plantations Di Samarinda. Hasil penelitian menunjukkan bahwa Insentif berpengaruh signifikan terhadap Produktivitas Kerja Karyawan Kantor Pada PT. Rea Kaltim Plantations Di Samarinda

\section{Kerangka Pemikiran}

Berdasarkan teori dan penelitian terdahulu diatas, maka kerangka berpikir pada penelitian ini adalah : 


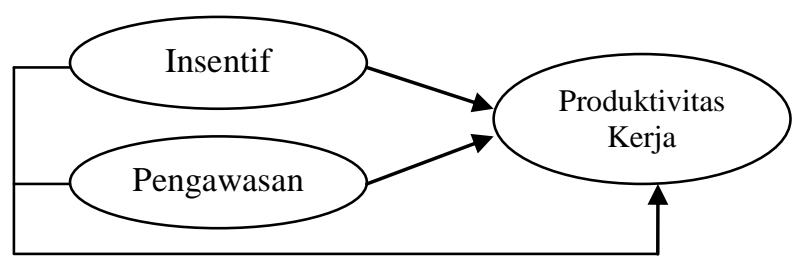

Gambar 1. Kerangka Pemikiran

\section{Hipotesis Penelitian}

Dalam kaitannya dengan pengaruh insentif dan pengawasan terhadap produktivitas Kerja Karyawan, maka dugaan sementara dari penelitian ini adalah sebagai berikut :

$\mathrm{H}_{1}$ : Ada pengaruh antara insentif dan pengawasan terhadap produktivitas kerja karyawan pada CV. Vassel Palembang

$\mathrm{H}_{2}$ : Ada pengaruh antara insentif terhadap produktivitas kerja karyawan pada CV. Vassel Palembang

$\mathrm{H}_{3}$ : Ada pengaruh antara pengawasan terhadap produktivitas kerja karyawan pada CV. Vassel Palembang.

\section{PROSEDUR PENELITIAN}

\section{Variabel Penelitian}

Variabel dalam penelitian ini terdiri dari dua variabel yaitu variabel bebas dan variabel terikat. Variabel bebas (variabel independen) merupakan variabel yang mempengaruhi atau yang menjadi sebab perubahannya atau timbulnya variabel dependen (terikat). Variabel bebas (X) dalam penelitian ini terdiri dari insentif $\left(\mathrm{X}_{1}\right)$ dan pengawasan $\left(\mathrm{X}_{2}\right)$. Variabel Terikat ( Variabel Dependen) merupakan variabel yang dipengaruhi atau yang menjadi akibat, karena adanya variabel bebas. Variabel terikat (Y) dalam penelitian ini adalah Produktivitas Kerja (Y).

\section{Defenisi Operasional Variabel}

\section{a. Insentif}

Insentif adalah daya perangsang yang diberikan kepada karyawan tetentu berdasarkan prestasi kerjanya agar karyawan terdorong meningkatkan produktivitas kerjanya dengan memberikan insentif yang mampu memberikan dorongan atau motivasi untuk bekerja (Hasibuan, 2013:183). Indikator yang digunakan bonus, komisi, pembagian laba (ProfitSharing), kompensasi yang di Tanngguhkan, jaminan sosial, pemberian piagam dan pemberian promosi.

\section{b. Pengawasan}

Suatu proses untuk menerapkan pekerjaan apa yang sudah dilaksanakan, menilainya, dan bila perlu mengoreksinya dengan maksud supaya pelaksanaan pekerjaan sesuai dengan rencana semula (Manullang, 2012:173). Dengan indikator menetapkan alat pengukur (standar), menilai (evaluasi) dan mengadakan tindakan perbaikan (corrective action).

\section{c. Produktivitas Kerja}

Produktivitas kerja adalah rasio dari hasil kerja dengan waktu yang di butuhkan untuk menghasilkan produk dari seorang tenaga kerja (Sutrisno, 2012:102). Indikator dalam penelitian ini adalah kemampuan, meningkatkan hasil, semangat kerja dan pengembangan diri.

\section{Populasi dan Sampel}

Menurut Sugiyono (2015:80) populasi adalah wilayah generalisasi yang terdiri atas objek atau subyek yang mempunyai kualitas dan karakteristik tertentu yang ditetapkan oleh peneliti untuk dipelajari dan kemudian ditarik kesimpulannya. Populasi dari penelitian ini adalah seluruh karyawan CV. Vassel sebanyak 34 orang. Pengambilan sampel dari penelitian ini 
teknik sampling jenuh. Sampling jenuh adalah teknik penentuan sampel bila semua anggota digunakan sebagai sampel. Istilah lain sampel jenuh adalah sensus, dimana dimana semua anggota populasi dijadikan sampel.

\section{Tehknik Pengumpulan Data}

Tehknik pengumpulan data dalam penulisan ini yaitu kuesioner atau Angket (Questionairre). Menurut Sujarweni (2015:94) kuesioner merupakan teknik pengumpulan data yang dilakukan dengan cara memberi seperangkat pentanyaan atau pernyataan tertulis kepada para responden untuk dijawab.

\section{Teknik Uji Coba Instrumen}

Penulis dalam penelitian menggunakan teknik uji instrumen meliputi uji validitas dan reliabilitas. Priyatno (2014:51) menjelaskan bahwa uji validitas adalah alat analisis untuk mengukur valid atau tidaknya suatu butir pertanyaan. Sedangkan uji reliabilitas menunjukkan tingkat konsistensi dan stabilitas dari data berupa skorhasil persepsi suatu variabel baik variabel bebas maupun variabel terikat. Uji validitas dilakukan dengan melakukan korelasi bivariate antara masing-masing skor indikator dengan total variabel. Untuk pengujian reliabilitas peneliti menggunakan alat ukur skala rentangan (seperti skala likert 1-5) yaitu croanbach's alpha diuji menggunakan bantuan komputer dengan program SPSS Versi 22.

\section{Uji Asumsi Klasik \\ a. Uji Normalitas}

Menurut Sunyoto (2013:84) uji asumsi normalitas akan menguji data variabel bebas $(\mathrm{X})$ dan data variabel terikat (Y) pada persamaan regresi yang dihasilkan, apakah berdistribusi normal atau berdistribusi tidak normal. Uji normalitas data dapat dilakukan dengan menggunakan uji Kolmogorov Smirnov satu arah. Pengambilan kesimpulan untuk menentukan apakah suatu data mengikuti distribusi normal atau tidak adalah. Jika signifikan > 0,05 maka variabel berdistribusi normal. Jika signifikan $<0,05$ maka variabel tidak berditribusi normal.

\section{b. Uji Multikolinearitas}

Menurut Priyatno menjelaskan bahwa uji asumsi klasik jenis ini diterapkan untuk menganalisis regresi berganda yang terdiri atas dua atau tiga variabel bebas/independent variabel. Uji multikolinearitas bertujuan untuk menguji apakah pada model regresi ditemukan kolerasi antar variabel bebas. Pada model regresi yang baik seharusnya tidak terjadi kolerasi diantara variabel bebas. Metode untuk menguji adanya multikolinearitas ini dapat dilihat dari Tolerance Value Variance Inflantion Factor (VIF). Jika $\mathrm{VIF}>10$ atau jika tolerance value $<0,1$ maka terjadi multikolinearitas. Jika VIF < 10 atau jika tolerance value $>0,1$ maka tidak terjadi multikolinearitas.

\section{c. Uji Heteroskedastisitas}

Menurut (Ghozali, 2013), uji heteroskedastisitas bertujuan menguji apakah dalam model regresi terjadi ketidaksamaan varians dari residual satu pengamatan ke pengamatan yang lain. Jika varians tetap maka disebut homoskedastisitas dan jika berbeda maka terjadi problem heteroskedastisitas. Model regresi yang baik yaitu homoskesdatisitas atau tidak terjadi heteroskedastisitas.

Untuk mendeteksi adanya
heteroskedastisitas dilakukan dengan
menggunakan teknik uji koefisien korelasi
spearman's rho yaitu mengorelasikan
variabel independen dengan residualnya.
Kriteria pengujian dengan menggunakan
tingkat signifikan 0,05 dengan uji 2 sisi.
Jika korelasi antara variabel indenpenden


dengan residualnya memberikan signifikan lebih dari 0,05, maka dapat dikatakan bahwa tidak terjadi problem heteroskedasitas.

\section{Teknik Analisis Data}

\section{a. Analisis Regresi Linier Berganda}

Priyatno (2014:148) mengemukakan bahwa analisis regresi ini bertujuan untuk mengetahui pengaruh atau hubungan secara linier antara dua atau lebih variabel bebas dengan variabel terikat. Analisis regresi ini dinyatakan dengan persamaan sebagai berikut :

$$
Y^{\prime}=\mathbf{a}+\mathbf{b}_{1} X_{1}+\mathbf{b}_{2} X_{2}+e
$$

\section{b. Koefisien Korelasi $\left(\mathbf{R}_{\mathrm{xy}}\right)$}

Menurut Sugiyono (2013:276) analisis koefisien korelasi digunakan untuk membandingkan hasil pengukuran dua variabel yang berbeda agar dapat menentukan hasil hubungan antara variabel.

\section{c. Koefisien Determinasi $\left(\mathbf{R}^{2}\right)$}

Koefisien determinasi $\left(\mathrm{R}^{2}\right)$ pada intinya mengukur seberapa jauh kemampuan model (stres kerja, konflik kerja) dalam menerangkan variasi variabel dependent atau tidak bebas (kinerja karyawan). Nilai koefisien determinasi adalah antara nol (0) dan (1). Nilai $\mathrm{R}^{2}$ yang kecil berarti kemampuan-kemampuan variabel independent (bebas) dalam menjelaskan variasi variabel dependent sangat terbatas.

Nilai yang mendekati satu (1) berarti variabel-variabel independent memberikan hampir semua informasi yang dibutuhkan untuk memprediksi variasi variabel dependent. Secara umum koefisien determinasi untuk data silang (crossection) relatif rendah karena adanya variasi yang besar antara masing-masing pengamatan, sedangkan untuk data runtun waktu (time series) biasanya mempunyai nilai koefisien determinasi yang tinggi.

\section{Pengujian Hipotesis \\ a. Uji t (Secara Parsial)}

Priyatno (2014:144) digunakan untuk mengetahui apakah masing-masing variabel bebasnya secara sendiri-sendiri berpengaruh secara signifikan terhadap variabel terikat dimana jika sig $>\alpha ́(0,05)$, maka $\mathrm{H}_{0}$ diterima dan $\mathrm{H}_{1}$ ditolak dan sebaliknya jika sig $<\alpha ́ \alpha(0,05)$ maka $\mathrm{H}_{0}$ ditolak dan $\mathrm{H}_{1}$ diterima. Penerimaan atau penolakan $\mathrm{H}_{0}$ dapat dilihat dari nilai probabilitas (sig F) dimana jika sig $<\alpha$ maka $\mathrm{H}_{0}$ ditolak dan $\mathrm{H}_{\mathrm{a}}$ diterima dan jika Sig $>\alpha$ maka $\mathrm{H}_{0}$ diterima dan $\mathrm{H}_{\mathrm{a}}$ ditolak.

\section{b. Uji F (Secara Simultan)}

Priyatno (2014:185) menjelaskan bahwa uji $\mathrm{F}$ berfungsi untuk mengetahui signifikasi pengaruh / hubungan antara semua variabel bebas dan variabel terikat. Penerimaan atau penolakan $\mathrm{H}_{0}$ dapat dilihat dari nilai probabilitas (sig F) dimana jika sig $<\alpha$ maka $\mathrm{H}_{0}$ ditolak dan $\mathrm{H}_{\mathrm{a}}$ diterima dan jika sig $>\alpha$ maka $\mathrm{H}_{0}$ diterima dan $\mathrm{H}_{\mathrm{a}}$ ditolak.

\section{HASIL PENELITIAN DAN PEMBAHASAN}

\section{Hasil Penelitian}

\section{a. Pengujian Instrumen}

\section{1) Uji Validitas}

Untuk menguji validitas kuesioner dalam penelitian ini digunakan rumus korelasi product moment yang dilakukan terhadap 34 responden. Analisis validitas kuesioner meliputi variabel insentif $\left(\mathrm{X}_{1}\right)$, pengawasan $\left(\mathrm{X}_{2}\right)$, dan produktivitas kerja (Y). Adapun hasil uji validitas kuesioner dapat diketahui pada tabel-tabel di bawah ini. 
Tabel 1 Hasil Uji Validitas

\begin{tabular}{|c|c|c|c|c|}
\hline Item & $\mathbf{r}_{\text {hitung }}$ & $\mathbf{r}_{\text {tabel }}$ & Kriteria & Ket. \\
\hline \multicolumn{5}{|l|}{$\begin{array}{l}\text { Insentif } \\
\left(\mathbf{X}_{1}\right)\end{array}$} \\
\hline Pernyataan 1 & 0,370 & 0,339 & $r_{\text {hitung }}>r_{\text {tabel }}$ & Valid \\
\hline Pernyataan 2 & 0,870 & 0,339 & $r_{\text {hitung }}>r_{\text {tabel }}$ & Valid \\
\hline Pernyataan 3 & 0,584 & 0,339 & $r_{\text {hitung }}>r_{\text {tabel }}$ & Valid \\
\hline Pernyataan 4 & 0,743 & 0,339 & $\mathrm{r}_{\text {hitung }}>\mathrm{r}_{\text {tabel }}$ & Valid \\
\hline Pernyataan 5 & 0,754 & 0,339 & $r_{\text {hitung }}>r_{\text {tabel }}$ & Valid \\
\hline Pernyataan 6 & 0,791 & 0,339 & $r_{\text {hitung }}>r_{\text {tabel }}$ & Valid \\
\hline Pernyataan 7 & 0,518 & 0,339 & $r_{\text {hitung }}>r_{\text {tabel }}$ & Valid \\
\hline Pernyataan 8 & 0,661 & 0,339 & $r_{\text {hitung }}>r_{\text {tabel }}$ & Valid \\
\hline Pernyataan 9 & 0,780 & 0,339 & $r_{\text {hitung }}>r_{\text {tabel }}$ & Valid \\
\hline Pernyataan 10 & 0,492 & 0,339 & $r_{\text {hitung }}>r_{\text {tabel }}$ & Valid \\
\hline \multicolumn{5}{|l|}{$\begin{array}{l}\text { Pengawasan } \\
\left(\mathbf{X}_{2}\right)\end{array}$} \\
\hline Pernyataan 1 & 0,575 & 0,339 & $r_{\text {hitung }}>r_{\text {tabel }}$ & Valid \\
\hline Pernyataan 2 & 0,468 & 0,339 & $\mathrm{r}_{\text {hitung }}>\mathrm{r}_{\text {tabel }}$ & Valid \\
\hline Pernyataan 3 & 0,479 & 0,339 & $r_{\text {hitung }}>r_{\text {tabel }}$ & Valid \\
\hline Pernyataan 4 & 0,732 & 0,339 & $r_{\text {hitung }}>r_{\text {tabel }}$ & Valid \\
\hline Pernyataan 5 & 0,600 & 0,339 & $r_{\text {hitung }}>r_{\text {tabel }}$ & Valid \\
\hline Pernyataan 6 & 0,775 & 0,339 & $r_{\text {hitung }}>r_{\text {tabel }}$ & Valid \\
\hline Pernyataan 7 & 0,578 & 0,339 & $\mathrm{r}_{\text {hitung }}>\mathrm{r}_{\text {tabel }}$ & Valid \\
\hline Pernyataan 8 & 0,677 & 0,339 & $r_{\text {hitung }}>r_{\text {tabel }}$ & Valid \\
\hline Pernyataan 9 & 0,836 & 0,339 & $r_{\text {hitung }}>r_{\text {tabel }}$ & Valid \\
\hline \multicolumn{5}{|l|}{$\begin{array}{l}\text { Produktivitas } \\
\text { kerja } \\
\text { (Y) }\end{array}$} \\
\hline Pernyataan 1 & 0,439 & 0,339 & $r_{\text {hitung }}>r_{\text {tabel }}$ & Valid \\
\hline Pernyataan 2 & 0,721 & 0,339 & $r_{\text {hitung }}>r_{\text {tabel }}$ & Valid \\
\hline Pernyataan 3 & 0,815 & 0,339 & $\mathrm{r}_{\text {hitung }}>\mathrm{r}_{\text {tabel }}$ & Valid \\
\hline Pernyataan 4 & 0,745 & 0,339 & $r_{\text {hitung }}>r_{\text {tabel }}$ & Valid \\
\hline Pernyataan 5 & 0,819 & 0,339 & $r_{\text {hitung }}>r_{\text {tabel }}$ & Valid \\
\hline Pernyataan 6 & 0,713 & 0,339 & $r_{\text {hitung }}>r_{\text {tabel }}$ & Valid \\
\hline Pernyataan 7 & 0,897 & 0,339 & $\mathrm{r}_{\text {hitung }}>\mathrm{r}_{\text {tabel }}$ & Valid \\
\hline Pertanyaan 8 & 0,808 & 0,339 & $r_{\text {hitung }}>r_{\text {tabel }}$ & Valid \\
\hline
\end{tabular}

Sumber: Data primer yang diolah, 2016

Berdasarkan tabel 1 diatas dapat diketahui bahwa nilai $\mathrm{r}_{\text {hitung }}$ korelasi product moment semua item pernyataan dari ketiga variabel yaitu insentif, pengawasan dan produktivitas kerja lebih besar dari pada nilai kritis $\left(\mathrm{r}_{\text {tabel }}\right)$ sebesar 0,339 pada tingkat kepercayaan $95 \%$. Dengan demikian, maka seluruh item pertanyaan dari ketiga variabel tersebut dinyatakan valid dan dapat digunakan sebagai alat pengumpulan data.

\section{2) Uji Reliabilitas}

Uji reliabilitas adalah tingkatan pada mana suatu tes secara koefisien mengukur berapa pun hasil pengukuran itu. Reliabilitas dinyatakan dengan angkaangka (biasanya sebagai suatu koefisien), koefisien yang tinggi menunjukkan reliabilitas yang tinggi. Hasil uji reliabilitas dalam penelitian ini menggunakan koefisien Cronbach Alpha, di mana instrumen dikatakan reliabel jika memiliki koefisien Cronbach Alpha > 0.60. Hasil uji reliabilitas data dapat dilihat pada tabel berikut:

Tabel 2

Hasil Uji Reliabilitas

\begin{tabular}{|c|l|c|c|}
\hline No & \multicolumn{1}{|c|}{ Variabel } & $\begin{array}{c}\text { Cronbabach } \\
\text { Alpha }\end{array}$ & Keterangan \\
\hline 1 & Insentif & 0,849 & Reliabel \\
\hline 2 & Pengawasan & 0,810 & Reliabel \\
\hline 3 & $\begin{array}{l}\text { Produktivitas } \\
\text { Kerja }\end{array}$ & 0,877 & Reliabel \\
\hline
\end{tabular}

Sumber: Data primer yang diolah, 2016

Hasil uji reliabilitas tersebut menunjukkan bahwa semua variabel mempunyai koefisien cronbach alpha yang besar, yaitu diatas 0.60 sehingga dapat disimpulkan bahwa item-item pengukur variabel dari kuesioner adalah reliabel yang berarti bahwa kuesioner yang digunakan dalam penelitian ini merupakan kuesioner yang handal.

\section{b. Uji Asumsi Klasik \\ 1) Uji Normalitas}

Dalam penelitian ini untuk menguji normalitas data penulis menggunakan teknik one sample Kolmogorov-Smirnov Test.

Tabel 3

\section{Hasil Uji Normalitas}

One-Sample Kolmogorov-Smirnov Test

\begin{tabular}{|ll|r|}
\hline & & $\begin{array}{c}\text { Unstandardized } \\
\text { Residual }\end{array}$ \\
\hline N & & 34 \\
Normal Parameters & a,b & Mean \\
& Std. Deviation &, 26679946 \\
Most Extreme Differences & Absolute &, 181 \\
& Positive &, 082 \\
& Negative & -181 \\
Kolmogorov-Smirnov Z & & 1,057 \\
Asymp. Sig. (2-tailed) & &, 214 \\
\hline
\end{tabular}

a. Test distribution is Normal.

b. Calculated from data.

Sumber: Data primer yang diolah, 2016

Berdasarkan hasil uji normalitas data menggunakan One Sample Kolmogorov Smirnov Test, sebagaimana tersaji pada 
tabel diatas dapat disimpulkan bahwa variabel memiliki data normal, hal tersebut dikarenakan data tersebut memiliki Asymp. Sig $>(\alpha) 0,05$.

\section{2) Uji Multikolinearitas}

Metode untuk menguji adanya multikolinearitas ini dapat dilihat dari Tolerance Value Variance Inflantion Factor (VIF). Jika VIF > 10 atau jika tolerance value $<0,1$ maka terjadi multikolinearitas. Jika VIF $<10$ atau jika tolerance value $>0,1$ maka tidak terjadi multikolinearitas.

Tabel 4

Hasil Uji Multikolinearitas

\begin{tabular}{|c|c|c|c|}
\hline Model & \multicolumn{2}{|c|}{$\begin{array}{c}\text { Collinearity } \\
\text { Statistics }\end{array}$} & \multirow{2}{*}{ Keterangan } \\
\cline { 1 - 2 } $\begin{array}{c}\text { Consta } \\
\text { nt }\end{array}$ & Tolerance & VIF & \\
\hline $\begin{array}{c}\text { Insenti } \\
\text { f }\end{array}$ & 0,653 & 1,532 & $\begin{array}{c}\text { Tidak ada } \\
\text { Multikolinearitas }\end{array}$ \\
\hline $\begin{array}{c}\text { Penga } \\
\text { wasan }\end{array}$ & 0,653 & 1,532 & $\begin{array}{c}\text { Tidak ada } \\
\text { Multikolinearitas }\end{array}$ \\
\hline
\end{tabular}

Sumber: Data primer yang diolah, 2016

Pada tabel 4 tersebut menunjukkan semua angka VIF variabel model regresi lebih kecil dari 10 (VIF < 10), hal ini menunjukkan model regresi linier berganda tidak mempunyai persoalan multikolinearitas. Hasil perhitungan nilai tolerance juga menunjukkan tidak ada varibel independen yang nilainya kurang dari 0,1 (tolerance > 0,1), yang berarti tidak ada korelasi antar variabel independen yang nilainya lebih dari $95 \%$, hal ini berarti tidak terjadi multikolinearitas.

\section{3) Uji Heteroskedasitas}

Untuk mendeteksi adanya heteroskedastisitas dilakukan dengan menggunakan teknik uji koefisien korelasi spearman's rho yaitu mengorelasikan variabel independen dengan residualnya. Kriteria pengujian dengan menggunakan tingkat signifikan 0,05 dengan uji 2 sisi. Jika korelasi antara variabel indenpenden dengan residualnya memberikan signifikan lebih dari 0,05, maka dapat dikatakan bahwa tidak terjadi problem heteroskedasitas.

\section{Tabel 5}

Hasil Uji Heteroskedasitas

\begin{tabular}{|c|c|c|c|c|c|}
\hline \multicolumn{6}{|c|}{ Correlations } \\
\hline & & & Insentif & Pengawasan & $\begin{array}{c}\text { Unstandardized } \\
\text { Residual }\end{array}$ \\
\hline \multirow{9}{*}{$\begin{array}{l}\text { Spearman's } \\
\text { rho }\end{array}$} & \multirow[t]{3}{*}{ Insentif } & Correlation Coefficient & 1,000 & .546 &,- 143 \\
\hline & & Sig. (2-tailed) & & .001 & .418 \\
\hline & & $\mathrm{N}$ & 34 & 34 & 34 \\
\hline & \multirow[t]{3}{*}{ Pengawasan } & Correlation Coefficient &, $546^{\prime \prime \prime}$ & 1,000 &,- 233 \\
\hline & & Sig. (2-tailed) &, 001 & & 185 \\
\hline & & $\mathrm{N}$ & 34 & 34 & 34 \\
\hline & \multirow{3}{*}{$\begin{array}{l}\text { Unstandardize } \\
\text { d Residual }\end{array}$} & Correlation Coefficient &,- 143 &,- 233 & 1,000 \\
\hline & & Sig. (2-tailed) & .418 & 185 & \\
\hline & & $\mathrm{N}$ & 34 & 34 & 34 \\
\hline
\end{tabular}

Sumber: Data primer yang diolah, 2016

Berdasarkan

hasil

uji heteroskedastisitas dengan menggunakan uji koefisien korelasi spearman's rho dapat dilihat bahwa korelasi antara variabel bebas (insentif dan pengawasan) dengan unstandardized residual memiliki nilai signifikan lebih besar dari 0,05. Karena signifikansi lebih besar daripada 0,05 , maka dapat disimpulkan bahwa tidak terjadi problem heteroskedasitas.

\section{c. Uji Regresi Linier Berganda}

Menurut Sugiyono (2014:275) uji regresi ganda digunakan oleh peneliti, bila peneliti bermaksud meramalkan bagaimana keadaan (naik turunnya) variabel dependen (kriterium), bila dua atau lebih variabel independen sebagai faktor prediktor dimanipulasi (dinaikturunkan nilainya). Jadi analisis regresi ganda akan dilakukan bila jumlah variabel independennya minimal 2 . Proses pengolahan data dilakukan dengan menggunakan program Statistical Package for the Social Science (SPSS) versi 22.0. Adapun hasil regresi linier berganda tersebut disajikan pada Tabel 4.37 berikut ini. 
Tabel 6

Hasil Uji Regresi Berganda

\begin{tabular}{|c|c|c|c|c|c|c|}
\hline \multicolumn{7}{|c|}{ Coefficients $^{a}$} \\
\hline \multirow[b]{2}{*}{ Model } & & \multicolumn{2}{|c|}{$\begin{array}{c}\text { Unstandardized } \\
\text { Coefficients }\end{array}$} & \multirow{2}{*}{$\begin{array}{c}\begin{array}{c}\text { Standardized } \\
\text { Coefficients }\end{array} \\
\text { Beta }\end{array}$} & \multirow[b]{2}{*}{$t$} & \multirow[b]{2}{*}{ Sig. } \\
\hline & & $B$ & Std. Error & & & \\
\hline \multirow[t]{3}{*}{1} & (Constant) &, 282 & .496 & & .570 & .573 \\
\hline & Insentif & .444 & , 134 & .435 & 3,311 & .002 \\
\hline & Pengawasan & .495 & .139 & .470 & 3,576 & .001 \\
\hline
\end{tabular}

Sumber: Data primer yang diolah, 2016

Berdasarkan tabel 6, dapat dibuat persamaan regresi linier berganda seperti berikut:

$\mathrm{Y}=0,282+0,444 \mathrm{X}_{1}+0,495 \mathrm{X}_{2}$

Berdasarkan hasil persamaan regresi linier berganda, maka dapat dianalisis sebagai berikut:

1) Nilai konstanta sebesar 0,282 berarti apabila ada peningkatan insentif dan pengawasan sebesar satu persen akan meningkatkan produktivitas kerja karyawan sebesar 28,2\%.

2) Koefisien regresi dari insentif sebesar 0,444 berarti bahwa peningkatan insentif sebesar satu persen akan meningkatkan produktivitas kerja karyawan sebesar 44,4\%.

3) Koefisien regresi dari pengawasan sebesar 0,495 berarti bahwa peningkatan pengawasan sebesar satu persen akan meningkatkan produktivitas kerja karyawan sebesar $49,5 \%$.

\section{d. Uji Korelasi dan Koefisien Determinasi $\left(\mathbf{R}^{2}\right)$ Berganda}

Uji korelasi ganda adalah suatu nilai yang memberikan kuatnya pengaruh atau hubungan dua variabel atau lebih secara bersama-sama dengan variabel lain. Sedangkan koefisien determinasi digunakan untuk mengetahui seberapa besar pengaruh variabel-variabel bebas memiliki pengaruh terhadap variabel terikatnya. Pengujian ini diuji dengan bantuan komputer dengan program SPSS Versi 22, dengan output sebagai berikut:
Tabel 7

Hasil Uji Korelasi dan Determinasi

Model Summary ${ }^{b}$

\begin{tabular}{|l|c|c|c|c|}
\hline Model & $\mathrm{R}$ & R Square & $\begin{array}{c}\text { Adjusted R } \\
\text { Square }\end{array}$ & $\begin{array}{c}\text { Std. Error of } \\
\text { the Estimate }\end{array}$ \\
\hline 1 &, $807^{\mathrm{a}}$ &, 651 &, 628 &, 27527 \\
\hline
\end{tabular}
a. Predictors: (Constant), Pengawasan, Insentif
b. Dependent Variable: Produktivitas Kerja

Sumber: Data primer yang diolah, 2016

Berdasarkan tabel di atas diperoleh nilai $\mathrm{R}$ sebesar $0,807^{\mathrm{a}}$ ini menunjukkan bahwa nilai $\mathrm{R}$ berada pada hubungan atau keeratan yang sangat kuat. Maka dapat disimpulkan bahwa variabel insentif dan pengawasan terdapat hubungan yang signifikan terhadap produktivitas kerja. Untuk koefisien determinasi (adjusted $\mathrm{R}^{2}$ ) dari hasil perhitungan dengan menggunakan program SPSS versi 22 dapat diketahui bahwa diperoleh nilai sebesar 0,628. Hal ini berarti 62,8\% produktivitas kerja karyawan dapat dijelaskan oleh variabel insentif dan pengawasan, sedangkan sisanya yaitu $37,2 \%$ dipengaruhi oleh variabel-variabel lainnya yang tidak diteliti dalam penelitian ini.

\section{e. Pengujian Hipotesis \\ 1) Hasil Uji F}

Uji $\mathrm{F}$ digunakan untuk mengetahui pengaruh variabel bebas (insentif dan pengawasan) secara serentak atau simultan terhadap variabel terikat (produktivitas kerja karyawan). Uji $\mathrm{F}$ ditujukan untuk mengukur tingkat keberartian hubungan secara keseluruhan koefisien regresi dari variabel bebas terhadap variabel terikat dengan menentukan nilai uji $\mathrm{F}$ dengan tabel ANOVA (analysis of variance) dan tingkat signifikansi. Hasil pengujian tersebut adalah sebagai berikut: 
Tabel 8

Hasil Uji F (Simultan)

ANOVA $^{\mathrm{a}}$

\begin{tabular}{|c|c|c|c|c|c|c|}
\hline Model & & $\begin{array}{l}\text { Sum of } \\
\text { Squares }\end{array}$ & df & Mean Square & $F$ & Sig. \\
\hline \multirow[t]{3}{*}{1} & Regression & 4,377 & 2 & 2,189 & 28,882 & $.000^{6}$ \\
\hline & Residual & 2,349 & 31 &, 076 & & \\
\hline & Total & 6,726 & 33 & & & \\
\hline
\end{tabular}

a. Dependent Variable: Produktivitas Kerja

b. Predictors: (Constant), Pengawasan, Insentif

Sumber: Data primer yang diolah, 2016

Pengujian secara simultan menunjukkan bahwa nilai $\mathrm{F}$ untuk model regresi adalah 28,882 dengan tingkat signifikansi $0,000<0,05$ maka tingkat signifikansi model regresi lebih kecil dari taraf nyata. Hasil ini menunjukkan bahwa variabel bebas yaitu insentif dan pengawasan secara simultan mempunyai pengaruh yang signifikan terhadap variabel terikat yaitu produktivitas kerja karyawan.

\section{2) Hasil Uji t}

Uji parsial (uji-t) dilakukan untuk menguji signifikansi pengaruh variabelvariabel bebas (insentif dan pengawasan) secara individual terhadap variabel terikat (produktivitas kerja karyawan) pada $\mathrm{CV}$. Vassel Palembang. Uji-t dalam penelitian ini digunakan untuk melakukan pengujian hipotesis dengan tingkat signifikansi $(\alpha=0,05)$. Uji-t ditunjukkan pada tabel 9 sebagai berikut:

\section{Tabel 9}

\section{Hasil Uji T (Parsial)}

Coefficients $^{\mathrm{a}}$

\begin{tabular}{|c|c|c|c|c|c|c|}
\hline & & \multicolumn{2}{|c|}{$\begin{array}{l}\text { Unstandardized } \\
\text { Coefficients }\end{array}$} & \multirow{2}{*}{$\begin{array}{c}\begin{array}{c}\text { Standardized } \\
\text { Coefficients }\end{array} \\
\text { Beta } \\
\end{array}$} & \multirow[b]{2}{*}{$t$} & \multirow[b]{2}{*}{ Sig. } \\
\hline \multicolumn{2}{|c|}{ Model } & $B$ & Std. Error & & & \\
\hline \multirow[t]{3}{*}{1} & (Constant) & 282 & .496 & & .570 & .573 \\
\hline & Insentif & .444 & .134 & .435 & 3,311 &, 002 \\
\hline & Pengawasan & 495 & 139 & 470 & 3.576 & 001 \\
\hline
\end{tabular}

Sumber: Data primer yang diolah, 2016

Berdasarkan hasil uji $\mathrm{t}$ pada tabel diatas maka diperoleh pengujian hipotesis dalam penelitian ini yaitu sebagai berikut : a) Uji Hipotesis Pertama
$\mathrm{H}_{1}$ : Ada pengaruh insentif terhadap produktivitas kerja karyawan pada CV. Vassel Palembang.

Berdasarkan tabel 9 menunjukkan bahwa nilai $t$ sebesar 3,311 dengan signifikansi $0,002<0,05$. Hasil penelitian ini membuktikan kebenaran hipotesis 1 (satu) atau insentif berpengaruh positif signifikan terhadap produktivitas kerja karyawan pada CV. Vassel Palembang.

b) Uji Hipotesis Kedua

$\mathrm{H}_{2}$ : Ada pengaruh pengawasan terhadap produktivitas kerja karyawan pada CV. Vassel Palembang.

Berdasarkan tabel 9 menunjukkan bahwa nilai $t$ sebesar 3,576 dengan signifikansi $0,001<0,05$. Hasil penelitian ini membuktikan kebenaran hipotesis 2 (dua) atau pengawas berpengaruh positif signifikan terhadap produktivitas kerja karyawan pada CV. Vassel Palembang.

\section{Pembahasan}

a. Pengaruh Insentif dan Pengawasan terhadap Produktivitas Kerja

Berdasarkan hasil uji $\mathrm{F}$ diperoleh nilai $F$ untuk model regresi adalah 28,882 dengan tingkat signifikansi $0,000<0,05$ maka tingkat signifikansi model regresi lebih kecil dari taraf nyata. Hasil ini menunjukkan bahwa variabel bebas yaitu insentif dan pengawasan secara simultan mempunyai pengaruh yang signifikan terhadap variabel terikat yaitu produktivitas kerja karyawan. Selain itu,

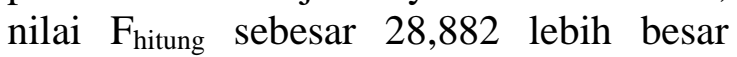
dibandingkan dengan nilai $\mathrm{F}_{\text {tabel }}$ sebesar 3,305 .

Pengaruh secara serempak antara variabel bebas dan variabel terikat memberikan informasi yang kuat yaitu dibuktikan dengan koefisien determinasi (Adjusted $R^{2}$ ). Koefisien determinasi (Adjusted $R^{2}$ ) pada intinya menerangkan sebanyak mungkin variasi dalam variabel 
terikat dengan menggunakan variabel bebas dalam model. Suatu model dikatakan baik jika diukur dengan menggunakan nilai Adjusted $R^{2}$ yang setinggi mungkin. Nilai koefisien determinasi adalah antara nol (0) dan satu (1). Nilai $\mathrm{R}^{2}$ yang kecil berarti kemampuan variabel-variabel independen (variabel bebas) dalam menjelaskan variasi variabel dependen amat terbatas. Nilai yang mendekati satu berarti variabel-variabel independen memberikan hampir semua informasi yang dibutuhkan untuk memprediksi variasi variabel dependen.

Hasil koefisien determinasi diperoleh nilai adjusted $R 2$ sebesar 0,628 atau $62,8 \%$. Hasil penelitian ini berarti bahwa $62,8 \%$ variasi variabel terikat yaitu produktivitas kerja karyawan dipengaruhi oleh variasi variabel bebas yaitu insentif dan pengawasan, sedangkan sisanya $37,2 \%$ dipengaruhi oleh faktor lainnya yang tidak dimasukkan ke dalam model tersebut. Pembahasan berdasarkan perhitungan analisis dapat dinyatakan bahwa pengaruh insentif dan pengawasan terhadap produktivitas kerja karyawan pada CV. Vassel Palembang adalah signifikan.

Hasil uji asumsi klasik juga membuktikan bahwa model regresi memenuhi persyaratan karena terbukti data-data yang digunakan dalam analisis berdistribusi normal dan tidak terjadi gejala multikolinearitas dan heteroskedastisitas (hasil pada pembahasan uji asumsi klasik). Berdasarkan analisis penelitian ini maka yang berpengaruh secara nyata terhadap produktivitas kerja karyawan yaitu insentif $\left(\mathrm{X}_{1}\right)$ berpengaruh positif signifikan, dan pengawasan $\left(\mathrm{X}_{2}\right)$ berpengaruh positif signifikan.

\section{b. Pengaruh Insentif terhadap Produktivitas Kerja}

Dari hasil regresi dapat dijelaskan bahwa variabel bebas Insentif berpengaruh signifikan terhadap variabel terikat Produktivitas Kerja, variabel insentif menunjukkan hasil yang positif, artinya tinggi rendahnya insentif akan berbanding lurus atau diikuti dengan tinggi rendahnya produktivitas kerja karyawan CV. Vassel. Hal ini didukung oleh hasil uji t dengan tingkat signifikansi 0,002 (signifikan < 0,05). Yang artinya kenaikan insentif menyebabkan perubahan produktivitas kerja. Dengan demikian jika tingkat insentif dinaikkan maka akan berpengaruh atau dengan kata lain akan meningkatkan produktivitas kerja karyawan

Hasil penelitian ini sejalan dengan teori Hasibuan (2013:183), Insentif adalah daya perangsang yang diberikan kepada karyawan tetentu berdasarkan prestasi kerjanya agar karyawan terdorong meningkatkan produktivitas kerjanya dengan memberikan insentif yang mampu memberikan dorongan atau motivasi untuk bekerja. Dengan adanya pemberian insentif maka pekerja lebih semangat lagi dalam bekerja sehingga dapat meningkatkan produktivitasnya dalam bekerja Hasil penelitian ini juga diperkuat oleh hasil penelitian terdahulu yang dilakukan oleh Siti Khafidhoh (2015) yang menemukan insentif berpengaruh signifikan terhadap Produktivitas tenaga kerja.

\section{c. Pengaruh Pengawasan terhadap Produktivitas Kerja}

Berdasarkan hasil penelitian pengawasan berpengaruh terhadap produktivitas kerja karyawan. Hal ini ditunjukkan dengan nilai $\beta=0,495$, hal ini dapat diartikan bahwa jika pengawasan meningkat maka produktivitas kerja karyawan akan meningkat positif. Hasil pengujian hipotesis menunjukkan bahwa nilai $t_{\text {hitung }}$ untuk pengawasan adalah 3,576 dengan signifikansinya sebesar 0,001, sedangkan pada taraf signifikansi sebesar 0,05 dengan df sebesar $=34$ diperoleh nilai $\mathrm{t}_{\text {tabel }}$ sebesar 2,039 sehingga nilai $\mathrm{t}_{\text {hitung }}$ $(3,576)>$ nilai $t_{\text {tabel }}(2,039)$. Dengan demikian menunjukkan bahwa ada pengaruh pengawasan terhadap 
produktivitas kerja karyawan pada $\mathrm{CV}$. Vassel Palembang. Kesimpulannya yaitu bahwa Ho ditolak dan Ha diterima, artinya ada pengaruh pengawasan terhadap produktivitas kerja karyawan pada CV. Vassel Palembang dapat diterima.

Hasil yang diperoleh diperkuat oleh penelitian yang dilakukan oleh Kartika Legawati (2014) dan Socha Summarjaya (2013) hasil penelitian menunjukkan bahwa pengawasan berpengaruh sangat signifikan terhadap produktivitas kerja karyawan. Hal ini berarti semakin baik pengawasan, maka semakin tinggi produktivitas kerja pegawai, sebaliknya semakin kurang baik pengawasan, maka semakin rendah produktivitas kerja pegawai. Pengawasan yang efektif akan meningkatkan kemampuan dan hasil kerja serta semangat kerja yang tinggi dari pegawai sehingga pegawai tersebut ingin mengembangkan dirinya agar menjadi pegawai yang lebih bermutu dan efisien. Dengan menciptakan pengawasan yang efektif akan meningkatkan produktivitas kerja pegawai.

\section{SIMPULAN}

\section{Kesimpulan}

Berdasarkan hasil penelitian serta hasil analisis data dan pembahasan yang telah diuraikan sebelumnya, maka dapat diambil kesimpulan hasil penelitian sebagai berikut :

a. Secara bersama-sama insentif dan pengawasan memiliki pengaruh yang signifikan terhadap produktivitas kerja karyawan pada CV. Vassel Palembang.

b. Secara parsial insentif memiliki pengaruh yang signifikan terhadap produktivitas kerja karyawan pada CV. Vassel Palembang.

c. Secara parsial pengawasan memiliki pengaruh yang signifikan terhadap produktivitas kerja karyawan pada CV. Vassel Palembang.

\section{Saran}

Sehubungan dengan hasil penelitian yang telah disimpulkan di atas, peneliti merumuskan beberapa saran pada pihak CV. Vassel sebagai berikut :

a. Untuk meningkatkan produktivitas kerja karyawan, pengetahuan dan keahlian karyawan secara berkelanjutan sebaiknya CV. Vassel selalu memberikan pengawasan yang intensif kepada karyawannya agar produktivitasnya juga meningkat.

b. Pihak perusahaan sebaknya meninjau ulang insentif yang telah diberikan kepada karyawan, agar produktivitas kerja karyawan dapat meningkat, sehingga tujuan kedua belah pihak baik perusahaan maupun karyawan dapat tercapai dengan baik.

c. Bagi peneliti yang akan akan meneliti pada permasalahan yang sejenis, diharapkan memasukkan variabel lain di luar variabel yang sudah ada dalam penelitian ini.

\section{DAFTAR PUSTAKA}

Bangun, Wilson, 2012, Manajemen Sumber Daya Manusia, Erlangga, Jakarta.

Diana dkk, 2008. Perilaku Organisasi. Jakarta: Salemba Empat. Edisi kelima. Yogyakarta: Unit Penerbit dan Percetakan Sekolah Tinggi Ilmu Manajemen YKPN.

Fahmi, Irham, 2011. Manajemen Teori, Kasus, dan Solusi. Cetakan Kesatu. Bandung: ALFABETA, cv.

Ghozali, Imam. 2013. Aplikasi Analisis Multivriate dengan Program SPSS. Semarang: Badan Penerbit Universitas Dipenogoro.

Hasibuan, Malayu S.P. 2013. Manajemen Sumber Daya Manusia. Penerbit Bumi Aksara, Jakarta. 
Irianto, Agus. 2011. Pendidikan sebagai Investasi dalam Pembangunan Suatu Bangsa. Jakarta: Kencana.

Khafidhoh, Siti. 2015. Pengaruh Insentif dan Jaminan Sosial Terhadap Produktivitas Kerja Karyawan Kantor Pada PT. Rea Kaltim Plantations di Samarinda. eJournal Administrasi Bisnis Fakultas Ilmu Sosial dan Ilmu Politik Universitas Mulawarman (FISIP UNMUL), Vol. 3 No. 3, tahun 2015.

Legawati, Kartika. 2014. Pengaruh Pengawasan Terhadap Produktivitas Kerja Karyawan Pabrik ( Kasus Karyawan Bagian Produksi PT. Pelita Agung Agrindustri di Duri). Jurusan Ilmu Administrasi Bisnis - Prodi Administrasi Bisnis Fakultas Ilmu Sosial dan Politik Universitas Riau. Jom FISIP Volume 1 No.2Oktober 2014.

Manullang, M. 2012. Dasar-dasar Manajemen. Cetakan Keduapuluh dua. Yogyakarta: Gadjah Mada University Press.

Priyatno, Duwi. 2014. SPSS Pengolahan Data Terpraktis. Yogyakarta: Andi Offset

Sugiyono. 2013. Metode Penelitian Manajemen. Cetakan pertama. Bandung:Alfabeta

Sugiyono. 2015. Metode Penelitian kuantitatif dan Kualitatif $R \& D$. Cetakan Ke-22 Bandung: Alfabeta

Sujarweni, V Wiratna. 2015. Metodologi Penelitian Bisnis \& Ekonomi. Cetakan Ke-1. Yogyakarta : PT. Pustaka Baru
Summarjaya, Socha. 2013. Pengaruh Pengawasan Terhadap

Produktivitas Kerja Pegawai Kantor Camat Menyuke Kabupaten Landak. Publika, Program Studi Ilmu Pemerintahan, Fakultas Ilmu Sosial dan Ilmu Politik, Universitas Tanjungpura Pontianak. Volume I, Nomor 01 Tahun 1, Januari 2013

Sunyoto, Danang. 2013. Analisis Regresi dan Uji Hipotesis. Cetakan Pertama. Jakarta : PT. Buku Kita.

Sutrisno, Edy. 2012. Manajemen Sumber Daya Manusia, Cetakan ke empat. Kencana Prenada Media Group. Jakarta.

Suwatno, dan Priansa. 2011. Manajemen Sumber Daya Manusia. Penerbita Alfabeta. Bandung

Wibowo, 2012. Manajemen Kinerja. Cetakan Keenam. Jakarta: PT. Raja Grafindo Persada.

Yani, Muhammad, 2012, Manajemen Sumber Daya Manusia. Mitra Waca Media, Jakarta.

Yuniarsih dan Suwatno. 2013. Manajemen Sumber Daya Manusia. Bandung: Alfabeta. 